\title{
Testosterone level and risk of type 2 diabetes in men: a systematic review and meta-analysis
}

\author{
Qiu-ming Yao', Bin Wang', Xiao-fei An ${ }^{1}$, Jin-an Zhang ${ }^{2}$ and Liumei Ding ${ }^{3}$ \\ ${ }^{1}$ Department of Endocrinology, Jinshan Hospital of Fudan University, Shanghai, China \\ ${ }^{2}$ Department of Endocrinology, Shanghai University of Medicine \& Health Sciences Affiliated Zhoupu Hospital, Shanghai, China \\ ${ }^{3}$ Department of Clinical Laboratory, Jinshan Hospital of Fudan University, Shanghai, China \\ Correspondence should be addressed to J Zhang or L Ding: zhangjinan@hotmail.com or dlm196969@163.com
}

\begin{abstract}
Background: Type 2 diabetes is a risk factor for testosterone deficiency and impaired sex steroid status. Some studies also investigated the association of testosterone level with diabetes risk in men, but reported controversial findings. To clarify this issue, we conducted a systematic review and meta-analysis.

Methods: PubMed, EMBASE and Web of Science were searched for eligible cohort or nested case-control studies published up to August 15, 2017. Meta-analysis was used to calculate the pooled relative risk (RR) of type 2 diabetes associated with higher testosterone level.

Results: Thirteen cohort or nested case-control studies with 16,709 participants were included. Meta-analysis showed that higher total testosterone level could significantly decrease the risk of type 2 diabetes in men ( $R R=0.65 ; 95 \% \mathrm{Cl} 0.50-0.84 ; P=0.001$ ), and higher free testosterone level could also decrease the risk of type 2 diabetes in men $(\mathrm{RR}=0.94 ; 95 \% \mathrm{Cl} 0.90-0.99 ; P=0.014)$. After excluding two studies that did not calculate RRs by quartiles of testosterone levels, both higher total testosterone and free testosterone levels could decrease the risk of type 2 diabetes in men, and the pooled RRs were 0.62 (95\% Cl 0.51-0.76; $P<0.001)$ and 0.77 (95\% Cl 0.61-0.98; $P=0.03$ ), respectively. Conclusion: This meta-analysis suggests that higher testosterone level can significantly decrease the risk of type 2 diabetes in men. Therefore, combined with previous researches, the findings above suggest a reverse-causality scenario in the relation between testosterone deficiency and risk of type 2 diabetes in men.
\end{abstract}

\author{
Key Words \\ - testosterone \\ - type 2 diabetes \\ - meta-analysis
}

\section{Introduction}

Diabetes is a public health issue, and there are over 0.4 billion people suffering from diabetes over the world, and its prevalence is still increasing remarkably every year (1). Type 2 diabetes mellitus (T2DM) is the major type of diabetes, which is associated with numerous complications including cardiovascular disease, peripheral neuropathy, stroke, infection, chronic renal failure, retinopathy and so on (2). Therefore, it is evident that both the treatment and the prevention of diabetes are critical. To compensate for progressive $\beta$-cell failure, standard treatment for T2DM includes lifestyle modification, oral hypoglycemic agents and insulin therapy. Besides, current pharmaceutical paradigm for T2DM is limited because they fail to maintain stable glucose control; furthermore, oral medications are associated with adverse effects that are involved in hypoglycemia, weight gain and the loss of bone (3). Therefore, further studies of the pathogenesis and risk factors of T2DM are still necessary to copy with the epidemic of T2DM.

There is evidence to indicate that endogenous sex hormones play a vital role in the pathogenesis of T2DM (4). Some studies proposed that testosterone was possibly

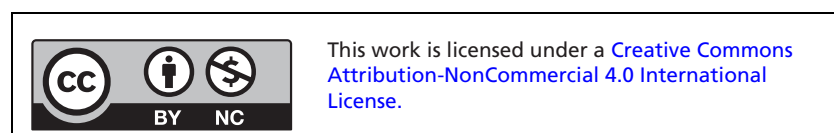


linked with T2DM risk (5). The study by Rohwer and coworkers found that low testosterone level was associated with higher risk for T2DM among men but lower risk for T2DM among women (6). Elabbay and coworkers found T2DM patients tended to have significantly lower testosterone level when compared with non-diabetic individuals (7). However, evidence is less convincing and somewhat controversial for the impact of testosterone on T2DM risk among men. The study by Lakshman and coworkers reported that free testosterone level was not associated with risk of T2DM among men (8). Another study by Holmboe and coworkers also found that low testosterone level were not a risk factor for T2DM (9). Therefore, it is still unclear whether circulating testosterone level has an obvious impact on T2DM risk among men. There is also short of a comprehensive estimation of the relationship between circulating testosterone level and T2DM risk in men. Therefore, the objective of this study was to investigate whether circulating testosterone level was associated with T2DM risk in men.

\section{Materials and methods}

\section{Search strategy and selection criteria}

PubMed, EMBASE and Web of Science were searched to identify eligible studies. We searched databases from January 1980 to August 15, 2017. We employed the following keywords and MeSH searches: (testosterone or hypogonadism) and (diabetes or diabetic or type 2 diabetes mellitus or T2DM) and longitudinal or prospective or nested or cohort. We did not use the language restriction. For more eligible studies, we retrieved the reference lists of relevant articles or reviews.

We used the following predefined inclusion criteria: (1) cohort or nested case-control studies; (2) studies assessing T2DM risk associated with testosterone level in men; (3) the outcomes of interest were the risk estimates of T2DM associated with total or free testosterone, such as hazard ratio (HR), relative risk (RR) and odds ratio (OR). In this meta-analysis, to make it more comprehensive, we evaluated the risk of T2DM associated with total testosterone and free testosterone separately.

\section{Data extraction and quality assessment}

Using a predesigned form, the data were extracted independently by two authors from each study. We resolved the disagreements by discussion among all authors.

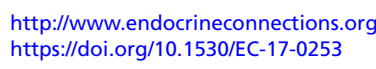

Data extracted from eligible studies mainly contained the first authors' name, publication year, study design, country, number of participants, duration of follow-up, types of testosterone, risk estimates and confounding factors used for adjustment analysis. If the study provided both unadjusted and adjusted risk estimates, we only used the latter one in our meta-analysis.

The study quality was assessed using the Newcastle Ottawa Scale (NOS) (10). According to its criteria, bias risk of included studies was assessed on selection of participants, comparability between groups (exposed and non-exposed participants), and the ascertainment of outcomes. Those three domains were scored by four stars, three stars and two stars, respectively. Studies with total stars of less than 6 were deemed to low-quality studies. Studies with 6 or more stars were regarded as moderate to high-quality studies.

\section{Statistical analysis}

Meta-analysis was used to calculate the pooled RRs of T2DM associated with testosterone. The $I^{2}$ and the Cochran's Q statistic were used to evaluate the heterogeneity $(11,12)$. For the $Q$ statistic, $P<0.10$ suggested statistically significant heterogeneity. $I^{2}$ more than 50\% also suggested substantial heterogeneity among included studies. Random-effect meta-analysis was used when substantial heterogeneity existed (13); otherwise, fixed-effect meta-analysis was used when heterogeneity was not significant (14). To explore the effects of individual study on the overall results, we also performed a sensitivity analysis by excluding studies by turns. Sensitivity analyses were also carried out by excluding two studies without RRs calculated by quartiles or tertiles of testosterone levels. Publication bias was evaluated by funnel plot and Egger's test (15). We used Stata (version 12.0) to perform this meta-analysis. The $P$ value $<0.05$ was considered significant difference.

\section{Results}

\section{Study selection and characteristics}

We identified 572 articles from literature search (Fig. 1). After reading titles and abstracts, most of them were excluded because some studies were not cohort or nested case-control studies or because the exposures or outcomes were not relevant to our analysis, leaving 36 articles to the stage of detailed evaluation. Then 24 studies were 
1294 potentially relevant studies identified through literature search

Pubmed $(\mathrm{n}=572)$

Embase $(\mathrm{n}=1309)$

Web of Science $(n=491)$

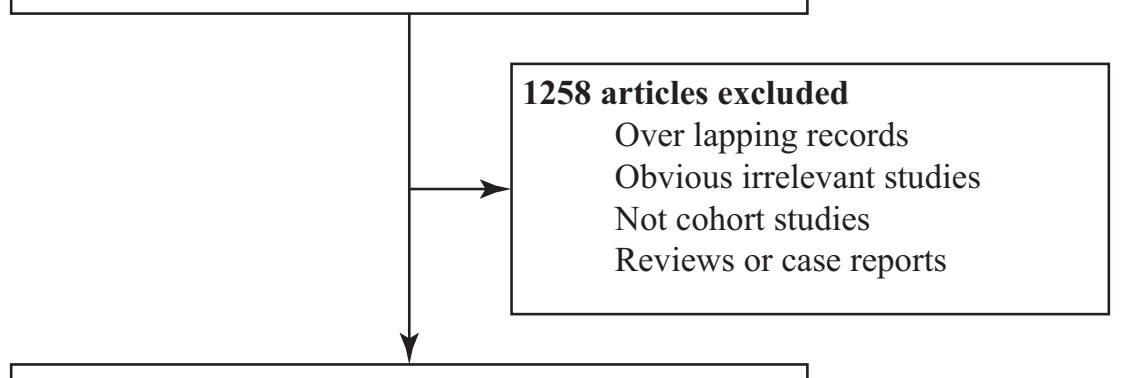

Full-text articles reviewed for more detailed evaluation $(n=36)$

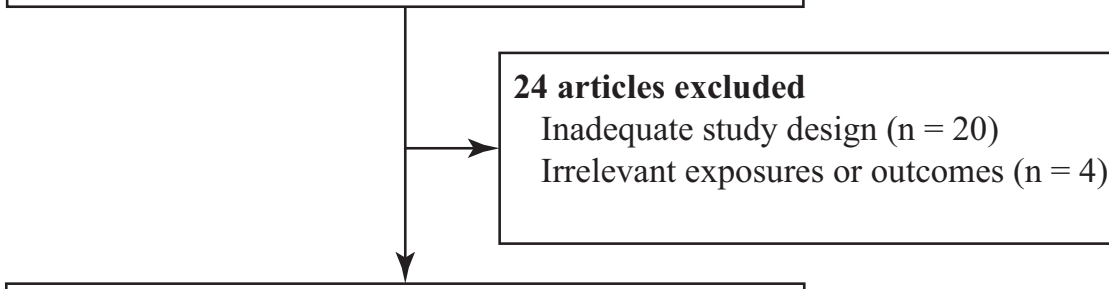

\section{2 studies were finally included}

Total testosterone $(\mathrm{n}=10)$

Free testosterone $(\mathrm{n}=8)$
Figure 1

Flowchart of study selection in the meta-analysis. excluded after reading their full-texts $(16,17,18,19,20$, $21,22,23,24,25,26,27,28,29,30,31,32,33,34,35,36$, $37,38)$. Finally, 12 studies were included into our metaanalysis $(9,39,40,41,42,43,44,45,46,47,48,49)$. There were a total of 16,709 participants.

We summarized and listed the main characteristics of the included studies in Table 1 . These included studies were published between 1996 and 2016, and all of them were published in English. All studies were done in developed countries, and only one study was performed in developing countries (Table 1). The time of follow-up ranged from 4.7 to 29 years. Ten studies reported RRs of T2DM associated with higher level of total testosterone, and 8 studies reported RRs of T2DM associated with higher level of free testosterone (Table 1). Ten of those 12 studies reported RRs calculated by quartiles or tertiles of testosterone levels, but two studies reported RRs calculated by some increment of testosterone levels $(47,49)$. Each study adjusted for a wide range of confounding factors, such as age, smoking, estradiol and so on. The quality of

http://www.endocrineconnections.org https://doi.org/10.1530/EC-17-0253

C) 2018 The authors Published by Bioscientifica Ltd those studies was shown in Table 1, and all studies had a high quality (Table 1).

\section{Meta-analysis}

Obvious heterogeneity was observed among those 10 studies on total testosterone $\left(I^{2}=64.6 \%\right)$, and randomeffect meta-analysis was utilized. Meta-analysis of those studies suggested that high level of total testosterone significantly decreased risk of T2DM among men (RR=0.65; 95\% CI 0.50-0.84, P=0.001; Fig. 2A). After excluding one study without RRs calculated by quartiles of testosterone levels, meta-analysis of those 9 left studies found that there was still an obvious association between high total testosterone level and decreased risk of T2DM among men $(\mathrm{RR}=0.62 ; 95 \%$ CI $0.51-0.76 ; \quad P<0.001$; Fig. 2B). In the sensitivity analysis by excluding studies by turns, the pooled RRs were not significantly altered by any single study (Fig. 3), suggesting no obvious impact of individual study on the overall results.

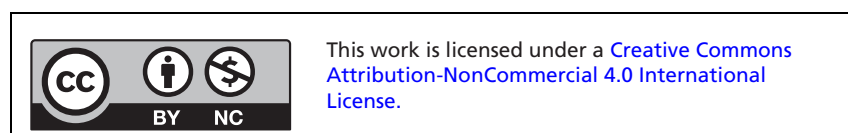


Table 1 The main characteristics of the included studies in the meta-analysis.

\begin{tabular}{|c|c|c|c|c|c|c|c|}
\hline Study & Design & Country & $\begin{array}{l}\text { Groups of participants } \\
\text { (mean age, years) }\end{array}$ & $\begin{array}{l}\text { Types of } \\
\text { testosterone }\end{array}$ & Follow-up & Confounding factors & Quality \\
\hline $\begin{array}{l}\text { Jasuja et al. } \\
(46)\end{array}$ & $\begin{array}{l}\text { Prospective } \\
\text { cohort }\end{array}$ & USA & $\begin{array}{l}1031 \text { men without } \\
\text { diabetes at baseline } \\
\text { which were from } \\
\text { Framingham Heart } \\
\text { Study (FHS) } \\
\text { generation } 2 \text { study } \\
\text { (59 years) }\end{array}$ & $\mathrm{TT}$ & 6.8 & $\begin{array}{l}\text { Age, smoking, BMI, } \\
\text { SHBG, and estradiol }\end{array}$ & 8 \\
\hline $\begin{array}{l}\text { Soriguer } \\
\text { et al. (45) }\end{array}$ & $\begin{array}{l}\text { Prospective } \\
\text { cohort }\end{array}$ & Spain & $\begin{array}{l}368 \text { men without } \\
\text { diabetes at baseline, } \\
\text { including } 57 \text { incident } \\
\text { T2DM cases and } 311 \\
\text { non-diabetic controls } \\
\text { during follow-up } \\
\text { (38 years) }\end{array}$ & fT & 11 & $\begin{array}{l}\text { Age and waist } \\
\text { circumference }\end{array}$ & 8 \\
\hline $\begin{array}{l}\text { Schipf et al. } \\
\text { (44) }\end{array}$ & $\begin{array}{l}\text { Prospective } \\
\text { cohort }\end{array}$ & Germany & $\begin{array}{l}1339 \text { men without } \\
\text { T2DM at baseline, } \\
\text { including } 68 \text { incident } \\
\text { T2DM cases and } 1271 \\
\text { non-diabetic controls } \\
\text { during follow-up } \\
\text { (50 years) }\end{array}$ & $\mathrm{TT}$ & 5 & $\begin{array}{l}\text { Age, waist } \\
\text { circumference, } \\
\text { smoking }\end{array}$ & 8 \\
\hline $\begin{array}{l}\text { Lakshman } \\
\text { et al. (43) }\end{array}$ & $\begin{array}{l}\text { Prospective } \\
\text { cohort }\end{array}$ & USA & $\begin{array}{l}1128 \text { men without } \\
\text { T2DM at baseline, } \\
\text { including } 90 \text { incident } \\
\text { T2DM cases and } 1038 \\
\text { non-diabetic controls } \\
\text { during follow-up } \\
\text { (54 years) }\end{array}$ & $\mathrm{TT} ; \mathrm{fT}$ & 13 & $\begin{array}{l}\text { Age, BMI, smoking, } \\
\text { high blood pressure, } \\
\text { alcohol intake, and } \\
\text { physical activity }\end{array}$ & 8 \\
\hline $\begin{array}{l}\text { Vikan et al. } \\
(42)\end{array}$ & $\begin{array}{l}\text { Prospective } \\
\text { cohort }\end{array}$ & Norway & $\begin{array}{l}1454 \text { men without } \\
\text { T2DM at baseline, } \\
\text { including } 76 \text { incident } \\
\text { T2DM cases and } 1378 \\
\text { non-diabetic controls } \\
\text { during follow-up } \\
\text { (59 years) }\end{array}$ & $\mathrm{TT} ; \mathrm{fT}$ & 9.1 & $\begin{array}{l}\text { Age, HDL cholesterol, } \\
\text { systolic blood } \\
\text { pressure, and waist } \\
\text { circumference }\end{array}$ & 8 \\
\hline $\begin{array}{l}\text { Oh et al. } \\
(40)\end{array}$ & $\begin{array}{l}\text { Prospective } \\
\text { cohort }\end{array}$ & USA & $\begin{array}{l}294 \text { men without } \\
\text { T2DM at baseline, } \\
\text { including } 26 \text { incident } \\
\text { T2DM cases and } 268 \\
\text { non-diabetic controls } \\
\text { during follow-up } \\
\text { (68 years) }\end{array}$ & TT & 8 & $\begin{array}{l}\text { Baseline age, BMI, and } \\
\text { systolic blood pressure }\end{array}$ & 7 \\
\hline $\begin{array}{r}\text { Laaksonen } \\
\text { et al. (41) }\end{array}$ & $\begin{array}{l}\text { Prospective } \\
\text { cohort }\end{array}$ & Finland & $\begin{array}{l}702 \text { men without } \\
\text { diabetes at baseline, } \\
\text { including } 57 \text { incident } \\
\text { T2DM cases and } 645 \\
\text { non-diabetic controls } \\
\text { during follow-up } \\
\text { (51 years) }\end{array}$ & $\mathrm{TT} ; \mathrm{fT}$ & 11 & $\begin{array}{l}\text { Age, presence of } \\
\text { cardiovascular disease, } \\
\text { smoking, alcohol } \\
\text { consumption, waist, } \\
\text { concentrations of } \\
\text { insulin, glucose, and } \\
\text { triglycerides, blood } \\
\text { pressure, etc. }\end{array}$ & 8 \\
\hline $\begin{array}{l}\text { Haffner } \\
\text { et al. (39) }\end{array}$ & $\begin{array}{l}\text { Nested } \\
\text { case-control }\end{array}$ & USA & $\begin{array}{l}176 \text { incident diabetes } \\
\text { male cases during } \\
\text { follow-up and } 352 \\
\text { matched non- } \\
\text { diabetic men } \\
\text { (46 years) }\end{array}$ & $\mathrm{TT} ; \mathrm{fT}$ & 5 & $\begin{array}{l}\text { Age, age, diastolic } \\
\text { blood pressure, serum } \\
\text { cholesterol, smoking, } \\
\text { fasting glucose, body } \\
\text { mass index, etc. }\end{array}$ & 7 \\
\hline
\end{tabular}

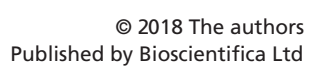

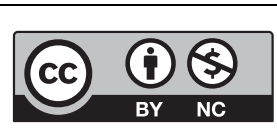

This work is licensed under a Creative Commons Attribution-NonCommercial 4.0 International License. 
Table 1 Continued

$\begin{array}{ll}\text { Study } & \text { Design } \\ \begin{array}{ll}\text { Joyce et al. } \\ \text { (47) }\end{array} & \begin{array}{c}\text { Prospective } \\ \text { cohort }\end{array}\end{array}$

$\begin{array}{ccc}\begin{array}{c}\text { Salminen } \\ \text { et al. (49) }\end{array} & \begin{array}{c}\text { Prospective } \\ \text { cohort }\end{array} & \text { Finland }\end{array}$

Holmboe et al. (9)

Country
(mean age, years)

852 men without

diabetes at baseline, including 112 incident T2DM cases and 740 non-diabetic controls during follow-up (76 years) 430 men without diabetes at baseline, including 30 incident T2DM cases and 400 non-T2DM controls during follow-up (72 years)

Denmark 5187 men without

diabetes at baseline, including 211 incident T2DM cases and 4976 nondiabetic controls during follow-up (not available)

Hu et al. (48) Nested China case-control

145 incident T2DM men during followup and 145 matched non-T2DM men (61 years)

\begin{tabular}{|c|c|c|c|}
\hline $\begin{array}{l}\text { Types of } \\
\text { testosterone }\end{array}$ & Follow-up & Confounding factors & Quality \\
\hline fT & 9.8 & $\begin{array}{l}\text { Age, race, site, alcohol } \\
\text { consumption, current } \\
\text { smoking status, and } \\
\text { BMI }\end{array}$ & 8 \\
\hline $\mathrm{TT} ; \mathrm{fT}$ & 9 & $\begin{array}{l}\text { BMI, fasting blood } \\
\text { glucose, } \\
\text { cardiovascular } \\
\text { diseases and sex } \\
\text { hormone-binding } \\
\text { globulin }\end{array}$ & 8 \\
\hline TT; fT & 29 & $\begin{array}{l}\text { BMI, study, alcohol } \\
\text { consumption and } \\
\text { exercise with age as } \\
\text { the underlying time } \\
\text { scale }\end{array}$ & 9 \\
\hline TT & 5 & $\begin{array}{l}\text { BMI, systolic blood } \\
\text { pressure, diastolic } \\
\text { blood pressure, } \\
\text { current smoking, } \\
\text { alcohol use, hyperten- } \\
\text { sion, exercise fre- } \\
\text { quency, family history } \\
\text { of T2DM, etc. }\end{array}$ & 9 \\
\hline
\end{tabular}

BMI, body mass index; fT, free testosterone; T2DM, type 2 diabetes mellitus; $\mathrm{TT}$, total testosterone.

Heterogeneity was not observed among those 8 studies on free testosterone $\left(I^{2}=17.9 \%\right)$, and fixedeffect meta-analysis was utilized. Meta-analysis of those studies suggested that high level of free testosterone was significantly associated with decreased risk of T2DM in men $(\mathrm{RR}=0.94 ; 95 \%$ CI 0.90-0.99; $P=0.014$; Fig. 4A). After excluding two studies without RRs calculated by quartiles of testosterone levels, meta-analysis of those 6 left studies found that high free testosterone level could decrease the risk of $\mathrm{T} 2 \mathrm{DM}$ in men $(\mathrm{RR}=0.77,95 \%$ CI $0.61-0.98$; $P=0.03$; Fig. 4B).

Funnel plot suggested no obvious tendency of publication bias in the meta-analysis of the association between total testosterone level and T2DM in men (Fig. 5, $P=0.17)$.

\section{Discussion}

Our study is the first meta-analysis of cohort studies to investigate the association between circulating testosterone level and T2DM risk in men. Twelve studies were finally included, and the findings suggested that high total testosterone level was significantly associated with decreased risk of T2DM in men $(\mathrm{RR}=0.65 ; 95 \% \mathrm{CI}$ $0.50-0.84 ; P=0.001)$. In addition, high free testosterone level was also significantly associated with decreased risk of T2DM in men $(\mathrm{RR}=0.94 ; 95 \%$ CI $0.90-0.99 ; P=0.014)$. Sensitivity analyses also found that high testosterone level was significantly associated with decreased risk of T2DM among men. The findings above suggest that testosterone has an important protective effect against T2DM among men, and men with higher testosterone level have a decreased risk for T2DM than those with lower testosterone level.

The findings of our meta-analysis indicate that male persons with a low testosterone level are predisposed to T2DM. Some mechanisms or hypotheses have been proposed to explain the association between testosterone and diabetes $(50,51)$. Firstly, the key role of insulin resistance in the pathogenesis of T2DM has been well http://www.endocrineconnections.org https://doi.org/10.1530/EC-17-0253 (c) 2018 The authors Published by Bioscientifica Ltd
This work is licensed under a Creative Commons Attribution-NonCommercial 4.0 International License. 


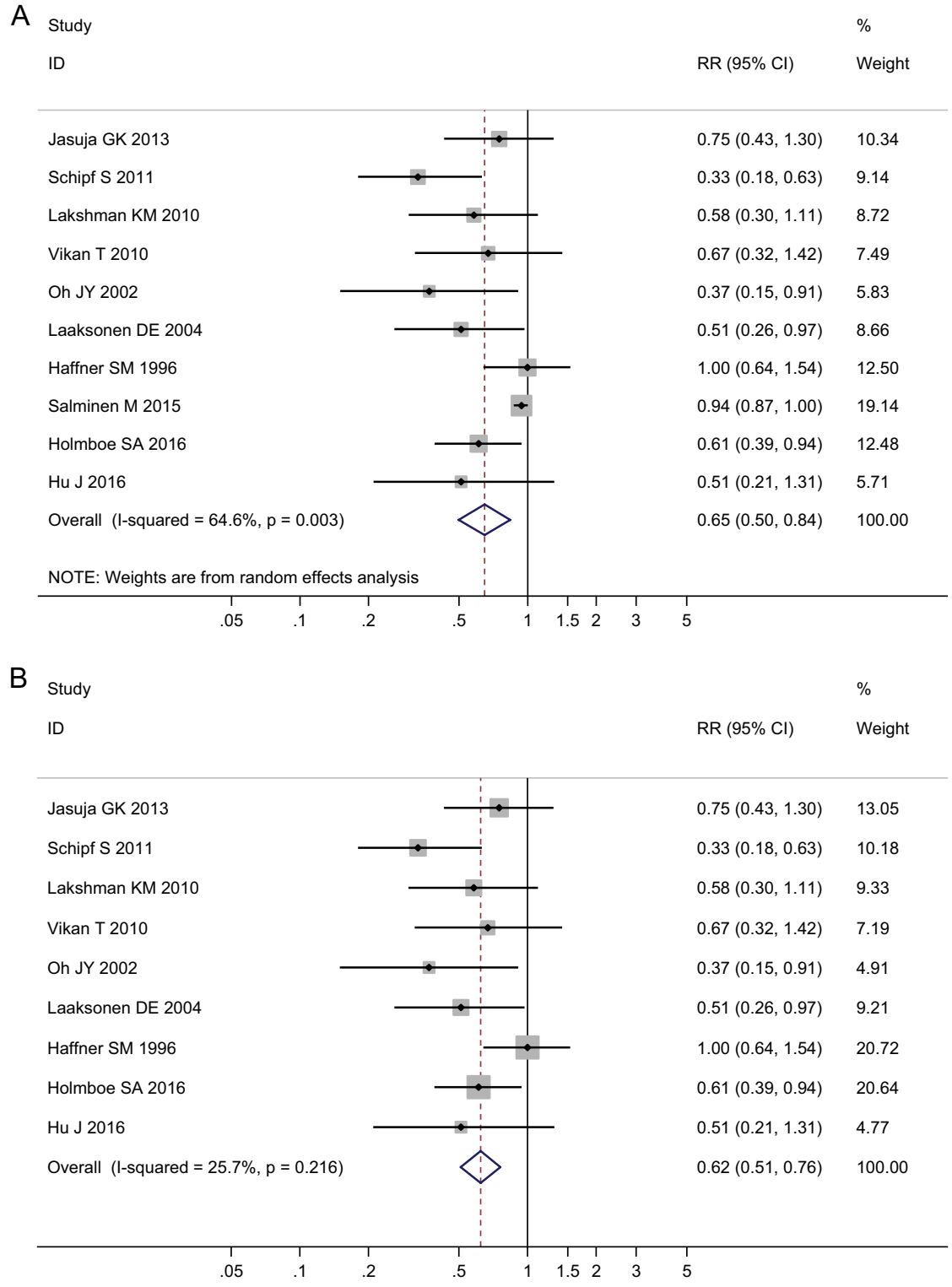

\begin{abstract}
Figure 2
Forest plots in the meta-analysis of the association between total testosterone level and T2DM in men. (A) Meta-analysis showed that high total testosterone level could obviously decrease the risk of T2DM among men (RR, relative risk; 95\% Cl, 95\% confidence interval). (B) Forest plot in the meta-analysis of 9 studies reporting RRs of T2DM calculated by quartiles or tertiles of total testosterone levels.
\end{abstract}

established. Previous studies have proven the inverse association between testosterone and insulin resistance, and individuals with testosterone deficiency have higher level of insulin resistance, which can further result in increased risk of T2DM $(52,53)$. An experimental study also supports that testosterone deficiency can increase fasting glucose associated with hepatic and extra-hepatic insulin resistance in adult male rats (54). Secondly, testosterone can regulate the expressions of important genes involved in insulin signaling and glucose uptake, such as glucose transporter-4 (GLUT4) $(55,56)$. Testosterone can increase the expression of GLUT4 in the muscle cells and adipocytes, and lower expression GLUT4 caused by testosterone deficiency decreases glucose transport and insulin responsiveness, which may finally cause T2DM. In one study, testicular feminized mice with testosterone deficiency have a reduced GLUT4 level in muscle and a decreased glycolytic enzyme activity in muscle, liver and abdominal adipose tissues (57). Thirdly, obesity caused by testosterone deficiency is another possible explanation. An experimental study by Fan and coworkers revealed that androgen receptor (AR) played an important role in modulating fat accumulation in male mice, and elimination of the effect of testosterone through AR knockout in mice promoted the development of obesity, which could further contribute to diabetes (58). Finally, abnormities in lipid metabolism are also involved in the pathogenesis of diabetes, which are associated with impaired insulin responsiveness and abnormalities in glucose control (59). The dysregulated lipid metabolism 


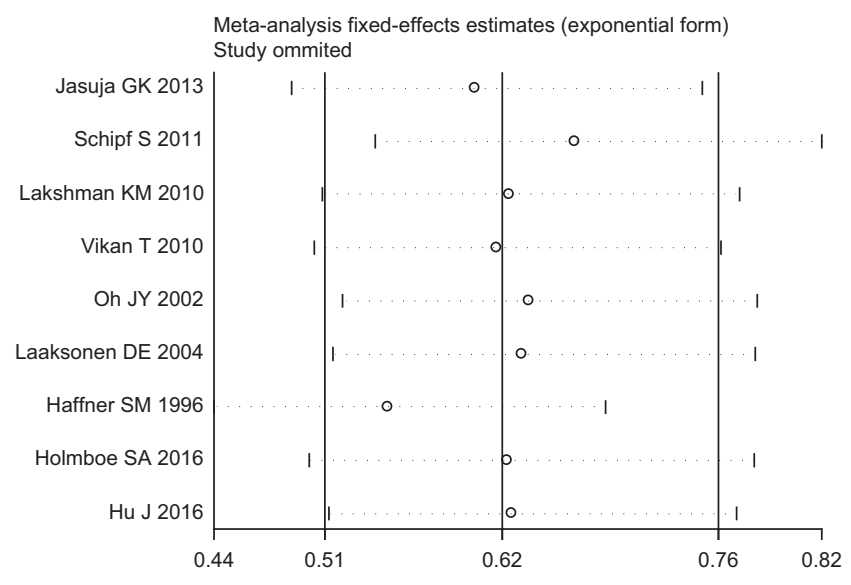

Figure 3

Sensitivity analysis by excluding studies by turns suggested that the pooled RRs were not significantly altered by any single study. caused by testosterone deficiency may result in decreased insulin sensitivity and increase the risk of T2DM $(60,61)$. However, the precise molecular mechanisms underlying the link of testosterone to T2DM are still not well defined.

The relationship between testosterone deficiency and diabetic predisposition implies that supplementation of testosterone may be a prophylactic means for T2DM in specific persons. A study by Canguven and coworkers found that testosterone therapy could decrease the levels of glycated hemoglobin, total cholesterol and triglycerides in elderly hypogonadal men, which might reduce the risk of diabetes in those individuals (62). It is not a unique instance, but has its counterpart. Permpongkosol and coworkers also reported that testosterone replacement could significantly decreased body fat and glycated hemoglobin in men with hypogonadism (63). An observational study by Yassin et al. found that testosterone

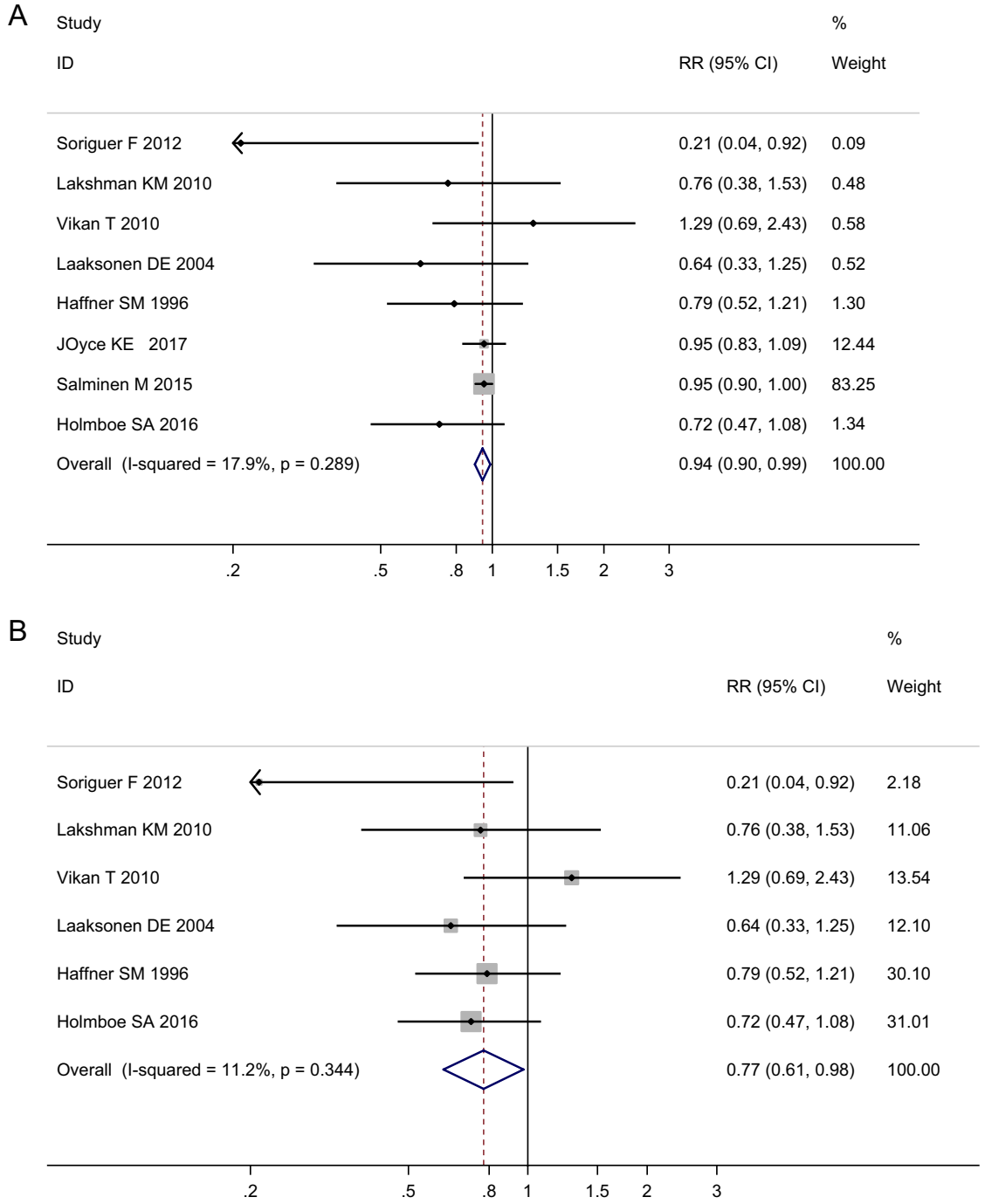

Figure 4

Forest plots in the meta-analysis of the association between free testosterone level and T2DM in men. (A) Meta-analysis showed that high free testosterone level could obviously decrease the risk of T2DM among men. (B) Forest plot in the meta-analysis of 6 studies reporting RRs of T2DM calculated by quartiles or tertiles of free testosterone levels. http://www.endocrineconnections.org https://doi.org/10.1530/EC-17-0253 (c) 2018 The authors Published by Bioscientifica Ltd

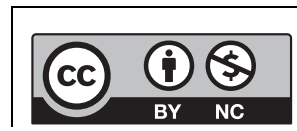

This work is licensed under a Creative Commons Attribution-NonCommercial 4.0 International License. 
Begg's funnel plot with pseudo 95\% confidence limits

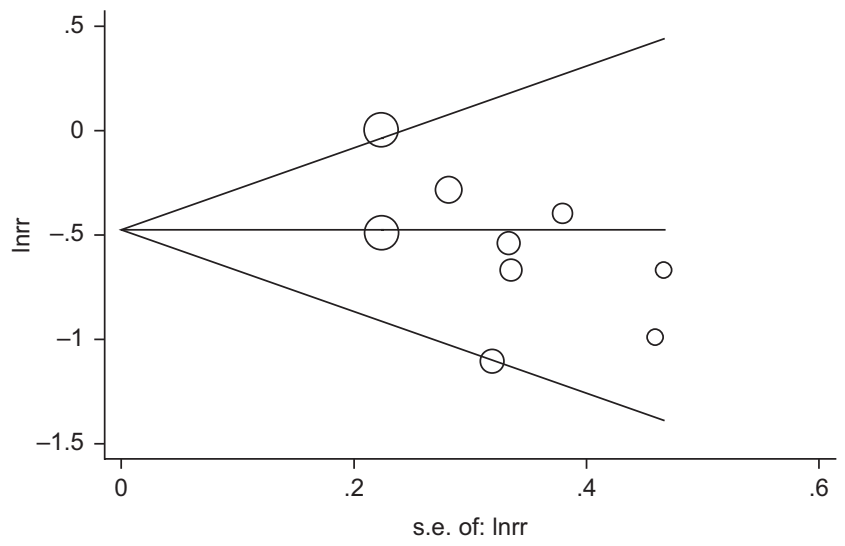

Figure 5

Funnel plot in the meta-analysis of the association between total testosterone and risk of T2DM in men.

application could decrease the levels of fasting glucose and HbA1c in hypogonadal elderly men (64). An experimental study using male mouse model of T2DM found that testosterone supplementation could improve glucose homeostasis (65). A clinical trial in men with lowered bioavailable testosterone level and T2DM found that testosterone therapy improved body composition and decreased HDL cholesterol level (66). Another study reported that testosterone therapy could reduce insulin resistance and improve glycemic control in hypogonadal men with type 2 diabetes (67). A recent clinical trial found that testosterone treatment in men with T2DM increased insulin sensitivity and reduced diabetic chronic inflammation (68). Though the above-mentioned findings strongly suggest that testosterone supplementation has a protective role against diabetes, more clinical trials are still needed to confirm this scenario, to determine the dosage and the approaches.

To summarize, our findings from the meta-analysis provide strong epidemiologic evidence for testosterone deficiency as an important risk factor of T2DM in men. As many observational studies have found that testosterone deficiency is very prevalent in male T2DM patients and also associated with poorer outcomes of diabetes (69, $70,71,72$ ), our research has a broad and bright clinical utilization in the future.

A previous systematic review published in 2006 also assessed the association between testosterone and diabetes (4). The systematic review above mainly included retrospective case-control or cross-sectional studies and included only two nested case-control studies, which was unable to evaluate the causal relationship between testosterone and T2DM. Compared with the previous systematic review, our study only included prospective cohort or nested case-control studies, which could assess the causal relationship between risk factor and diseases. We finally included 13 cohort or nested case-control studies, and the sample size of the pooled subjects was large enough to allow a reliable assessment of the causal relationship between testosterone and risk of T2DM in men. The pooled results in our meta-analysis provided strong epidemiological evidence for the causal relationship between testosterone and T2DM. Moreover, in the sensitivity analyses, the consistent and obvious links of testosterone with T2DM further strengthened the epidemiological evidence for testosterone as a protective factor against T2DM in men. The results of the present meta-analysis are very helpful to define the causal association between testosterone deficiency and T2DM.

Thus, there are many studies might support that testosterone deficiency leads to T2DM as described earlier. However, other studies suggest that T2DM is a risk factor for testosterone deficiency and impaired sex steroid status (73). One large prospective study showed that the development of T2DM is a major driver of the age-related testosterone decline (74). Treatment of hypogonadal men concomitant with T2DM with rosiglitazone caused an increase in serum testosterone levels (75). Another study demonstrated a significant reduction in total and free testosterone levels in men after glucose ingestion (76). Therefore, it seems that both insulin resistance and glucose itself may induce hypotestosteronaemia in patients with diabetes. About the impact of insulin resistance on testosterone, one longitudinal study indicated a negative correlation between changes in insulin resistance and alterations in testosterone levels in diabetic men over time (77). IL- 6 and TNF- $\alpha$, two major inflammatory cytokines related to insulin resistance in T2DM, are able to reduce the production of testosterone from Leydig cells (79). In addition, TNF- $\alpha$ and IL-1 $\beta$ have been shown to suppress secretion of hypothalamic gonadotropin-releasing hormone in experimental animals (80). Hence, there appears to be a bidirectional link between lower testosterone levels and T2DM, and a reverse-causality scenario exists in the relation between testosterone deficiency and T2DM risk in men.

Several limitations of the meta-analysis should be considered. Firstly, in the meta-analysis on the impact of total testosterone on T2DM risk among men, there was obvious heterogeneity which may be a result of the different study design, different statistical analysis or different characteristics of recruited subjects. Secondly, there were no uniform criteria for high or low testosterone

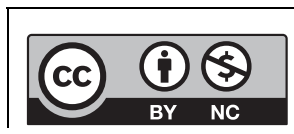

This work is licensed under a Creative Commons Attribution-NonCommercial 4.0 International License. 
levels among those included studies. At present, the adequate cut-off value in defining low testosterone level is still unclear, which needs to be defined in future research. Finally, most of our included studies were from European countries and USA, and only one study was conducted in Asia. Therefore, given above limitations, the findings from the present meta-analysis should be treated with caution.

In conclusion, this meta-analysis suggests that higher testosterone level can significantly decrease the risk of T2DM in men, and testosterone is an important protective factor against T2DM in men. Besides, more researches are recommended to evaluate the effect of testosterone supplementation in reducing T2DM risk in individuals with testosterone deficiency and to assess the effect of testosterone treatment in improving clinical outcomes among male patients with T2DM.

\section{Declaration of interest}

The authors declare no conflict of interest. They are all responsible for the content of the paper.

\section{Funding}

This work was supported by the National Natural Science Foundation of China (grant number 81270871) and the Key Disciplines Development of Shanghai Jinshan District (grant number JSZK2015A02).

\section{Author contribution statement}

Qiu-ming Yao, Bin Wang and Xiao-fei An designed the study. Qiuming Yao and Bin Wang extracted the data. Qiuming Yao and Bin Wang performed the analyses. Qiuming Yao wrote the draft. Jinan Zhang and Liumei Ding revised it critically.

\section{References}

1 NCD Risk Factor Collaboration (NCD-RisC). Worldwide trends in diabetes since 1980: a pooled analysis of 751 population-based studies with 4.4 million participants. Lancet $2016 \mathbf{3 8 7} 1513-1530$ (https://doi.org/10.1016/S0140-6736(16)00618-8)

2 Nathan DM. Long-term complications of diabetes mellitus. New England Journal of Medicine 1993328 1676-1685. (https://doi. org/10.1056/NEJM199306103282306)

3 Gasser E, Moutos CP, Downes M \& Evans RM. FGF1 - a new weapon to control type 2 diabetes mellitus. Nature Reviews Endocrinology 201713 599-609. (https://doi.org/10.1038/nrendo.2017.78)

4 Ding EL, Song Y, Malik VS \& Liu S. Sex differences of endogenous sex hormones and risk of type 2 diabetes: a systematic review and meta-analysis. JAMA 2006295 1288-1299. (https://doi.org/10.1001/ jama.295.11.1288)

5 Oh JY, Barrett-Connor E, Wedick NM \& Wingard DL. Endogenous sex hormones and the development of type 2 diabetes in older men and women: the Rancho Bernardo study. Diabetes Care 200225 55-60. (https://doi.org/10.2337/diacare.25.1.55)

6 Rohwer RD, Liu S, You NC, Buring JE, Manson JE \& Song Y. Interrelationship between alcohol intake and endogenous sexsteroid hormones on diabetes risk in postmenopausal women. https://doi.org/10.1530/EC-17-0253 http://www.endocrineconnections.org
() 2018 The authors Published by Bioscientifica Ltd
Journal of the American College of Nutrition 201534 273-280. (https:// doi.org/10.1080/07315724.2014.926163)

7 Elabbady A, Hashad MM, Kotb AF \& Ghanem AE. Studying the 156-159. (https://doi.org/10.1016/j.prnil.2016.07.005)

8 Lakshman KM, Bhasin S \& Araujo AB. Sex hormone-binding globulin as an independent predictor of incident type 2 diabetes mellitus in men. Journal of Gerontology: Series A, Biological Sciences and Medical Sciences 201065 503-509. (https://doi.org/10.1093/ gerona/glq002)

9 Holmboe SA, Jensen TK, Linneberg A, Scheike T, Thuesen BH, Skakkebaek NE, Juul A \& Andersson AM. Low testosterone: a risk marker rather than a risk factor for type 2 diabetes. Journal of Clinical Endocrinology and Metabolism 2016101 3180-3190. (https://doi. org/10.1210/jc.2016-1778)

10 Margulis AV, Pladevall M, Riera-Guardia N, Varas-Lorenzo C, Hazell L, Berkman ND, Viswanathan M \& Perez-Gutthann S. Quality assessment of observational studies in a drug-safety systematic review, comparison of two tools: the Newcastle-Ottawa Scale and the RTI item bank. Clinical Epidemiology 20146 359-368. (https:// doi.org/10.2147/CLEP.S66677)

11 Higgins JP, Thompson SG, Deeks JJ \& Altman DG. Measuring inconsistency in meta-analyses. BMJ 2003327 557-560. (https://doi. org/10.1136/bmj.327.7414.557)

12 Cochran WG. The combination of estimates from different experiments. Biometrics 195410 101-129. (https://doi. org/10.2307/3001666)

13 DerSimonian R \& Laird N. Meta-analysis in clinical trials. Controlled Clinical Trials 19867 177-188. (https://doi.org/10.1016/01972456(86)90046-2)

14 Mantel N \& Haenszel W. Statistical aspects of the analysis of data from retrospective studies of disease. Journal of the National Cancer Institute 195922 719-748.

15 Egger M, Davey SG, Schneider M \& Minder C. Bias in meta-analysis detected by a simple, graphical test. BMJ 1997315 629-634. (https://doi.org/10.1136/bmj.315.7109.629)

16 Lindstedt G, Lundberg PA, Lapidus L, Lundgren H, Bengtsson C \& Bjorntorp P. Low sex-hormone-binding globulin concentration as independent risk factor for development of NIDDM. 12-yr follow-up of population study of women in Gothenburg, Sweden. Diabetes 199140 123-128. (https://doi.org/10.2337/diab.40.1.123)

17 Haffner SM, Valdez RA, Morales PA, Hazuda HP \& Stern MP. Decreased sex hormone-binding globulin predicts noninsulindependent diabetes mellitus in women but not in men. Journal of Clinical Endocrinology and Metabolism 199377 56-60. (https://doi. org/10.1210/jcem.77.1.8325960)

18 Okubo M, Tokui M, Egusa G \& Yamakido M. Association of sex hormone-binding globulin and insulin resistance among JapaneseAmerican subjects. Diabetes Research and Clinical Practice 200047 71-75. (https://doi.org/10.1016/S0168-8227(99)00106-0)

19 Stellato RK, Feldman HA, Hamdy O, Horton ES \& McKinlay JB. Testosterone, sex hormone-binding globulin, and the development of type 2 diabetes in middle-aged men: prospective results from the Massachusetts male aging study. Diabetes Care 200023 490-494. (https://doi.org/10.2337/diacare.23.4.490)

20 Rosmond R, Wallerius S, Wanger P, Martin L, Holm G \& Bjorntorp P. A 5-year follow-up study of disease incidence in men with an abnormal hormone pattern. Journal of Internal Medicine 2003254 386-390. (https://doi.org/10.1046/j.1365-2796.2003.01205.x)

21 Kameda W, Daimon M, Oizumi T, Jimbu Y, Kimura M, Hirata A, Yamaguchi $\mathrm{H}$, Ohnuma $\mathrm{H}$, Igarashi $\mathrm{M}$, Tominaga $\mathrm{M}$, et al. Association of decrease in serum dehydroepiandrosterone sulfate levels with the progression to type 2 diabetes in men of a Japanese population: the Funagata study. Metabolism-Clinical and Experimental 200554 669-676. (https://doi.org/10.1016/j.metabol.2004.12.011) effect of type 2 diabetes mellitus on prostate-related parameters: a prospective single institutional study. Prostate International 20164

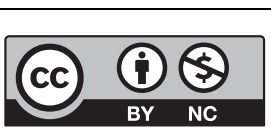

This work is licensed under a Creative Commons Attribution-NonCommercial 4.0 International License. 
22 Ding EL, Song Y, Manson JE, Rifai N, Buring JE \& Liu S. Plasma sex steroid hormones and risk of developing type 2 diabetes in women: a prospective study. Diabetologia 200750 2076-2084. (https://doi. org/10.1007/s00125-007-0785-y)

23 Goto A, Morita A, Goto M, Sasaki S, Miyachi M, Aiba N, Terauchi Y, Noda M \& Watanabe S. Associations of sex hormonebinding globulin and testosterone with diabetes among men and women (the Saku diabetes study): a case control study. Cardiovascular Diabetology 201211 130. (https://doi. org/10.1186/1475-2840-11-130)

24 Kalyani RR, Franco M, Dobs AS, Ouyang P, Vaidya D, Bertoni A, Gapstur SM \& Golden SH. The association of endogenous sex hormones, adiposity, and insulin resistance with incident diabetes in postmenopausal women. Journal of Clinical Endocrinology and Metabolism 200994 4127-4135. (https://doi.org/10.1210/jc.20090910)

25 Chen BH, Brennan K, Goto A, Song Y, Aziz N, You NC, Wellons MF, Manson JE, White DL, Butch AW, et al. Sex hormone-binding globulin and risk of clinical diabetes in American black, Hispanic, and Asian/Pacific Islander postmenopausal women. Clinical Chemistry 201258 1457-1466. (https://doi.org/10.1373/ clinchem.2012.193086)

26 Monroe AK, Dobs AS, Cofrancesco JJ \& Brown TT. Testosterone and abnormal glucose metabolism in an inner-city cohort. Journal of Men's Health 20129 154-159. (https://doi.org/10.1016/j. jomh.2012.03.010)

27 Muka T, Nano J, Jaspers L, Meun C, Bramer WM, Hofman A, Dehghan A, Kavousi M, Laven JS \& Franco OH. Associations of steroid sex hormones and sex hormone-binding globulin with the risk of type 2 diabetes in women: a population-based cohort study and meta-analysis. Diabetes 201766 577-586. (https://doi. org/10.2337/db16-0473)

28 Elabbady A, Hashad MM, Kotb AF \& Ghanem AE. Studying the effect of type 2 diabetes mellitus on prostate-related parameters: A prospective single institutional study. Prostate International 20164 156-159. (https://doi.org/10.1016/j.prnil.2016.07.005)

29 Cheung KK, Lau ES, So WY, Ma RC, Ozaki R, Kong AP, Chow FC, Chan JC \& Luk AO. Low testosterone and clinical outcomes in Chinese men with type 2 diabetes mellitus - Hong Kong Diabetes Registry. Diabetes Research and Clinical Practice 2017123 97-105. (https://doi.org/10.1016/j.diabres.2016.11.012)

30 Brahimaj A, Muka T, Kavousi M, Laven JS, Dehghan A \& Franco OH. Serum dehydroepiandrosterone levels are associated with lower risk of type 2 diabetes: the Rotterdam Study. Diabetologia 201760 98-106. (https://doi.org/10.1007/s00125-016-4136-8)

31 Atlantis E, Fahey P, Martin S, O'Loughlin P, Taylor AW, Adams RJ, Shi Z \& Wittert G. Predictive value of serum testosterone for type 2 diabetes risk assessment in men. BMC Endocrine Disorders 201616 26. (https://doi.org/10.1186/s12902-016-0109-7)

32 Calderon B, Gomez-Martin JM, Vega-Pinero B, Martin-Hidalgo A, Galindo J, Luque-Ramirez M, Escobar-Morreale HF \& BotellaCarretero JI. Prevalence of male secondary hypogonadism in moderate to severe obesity and its relationship with insulin resistance and excess body weight. Andrology 20164 62-67. (https:// doi.org/10.1111/andr.12135)

33 Tint AN, Hoermann R, Wong H, Ekinci EI, MacIsaac RJ, Jerums G, Zajac JD \& Grossmann M. Association of sex hormone-binding globulin and free testosterone with mortality in men with type 2 diabetes mellitus. European Journal of Endocrinology 2016174 59-68. (https://doi.org/10.1530/EJE-15-0672)

34 Fenske B, Kische H, Gross S, Wallaschofski H, Volzke H, Dorr M, Nauck M, Keevil BG, Brabant G \& Haring R. Endogenous androgens and sex hormone-binding globulin in women and risk of metabolic syndrome and type 2 diabetes. Journal of Clinical Endocrinology and Metabolism 2015100 4595-4603. (https://doi.org/10.1210/jc.20152546)
35 Daka B, Langer RD, Larsson CA, Rosen T, Jansson PA, Rastam L \& Lindblad $\mathrm{U}$. Low concentrations of serum testosterone predict acute myocardial infarction in men with type 2 diabetes mellitus. BMC Endocrine Disorders 201515 35. (https://doi.org/10.1186/s12902-0150034-1)

36 Hou WW, Tse MA, Lam TH, Leung GM \& Schooling CM. Adolescent testosterone, muscle mass and glucose metabolism: evidence from the 'Children of 1997' birth cohort in Hong Kong. Diabetic Medicine 201532 505-512. (https://doi.org/10.1111/dme.12602)

37 Yeap BB, Knuiman MW, Divitini ML, Handelsman DJ, Beilby JP, Beilin J, McQuillan B \& Hung J. Differential associations of testosterone, dihydrotestosterone and oestradiol with physical, metabolic and health-related factors in community-dwelling men aged 17-97 years from the Busselton Health Survey. Clinical Endocrinology 201481 100-108. (https://doi.org/10.1111/cen.12407)

38 Zhang J, Huang X, Liao M, Gao Y, Tan A, Yang X, Zhang H, Mo L, Zhang Y, Lu Z, et al. Both total testosterone and sex hormonebinding globulin are independent risk factors for metabolic syndrome: results from Fangchenggang Area Male Health and Examination Survey in China. Diabetes/Metabolism Research and Reviews 201329 391-397. (https://doi.org/10.1002/dmrr.2405)

39 Haffner SM, Shaten J, Stern MP, Smith GD \& Kuller L. Low levels of sex hormone-binding globulin and testosterone predict the development of non-insulin-dependent diabetes mellitus in men. MRFIT Research Group. Multiple Risk Factor Intervention Trial. American Journal of Epidemiology 1996143 889-897. (https://doi. org/10.1093/oxfordjournals.aje.a008832)

40 Oh JY, Barrett-Connor E, Wedick NM \& Wingard DL. Endogenous sex hormones and the development of type 2 diabetes in older men and women: the Rancho Bernardo study. Diabetes Care 200225 55-60. (https://doi.org/10.2337/diacare.25.1.55)

41 Laaksonen DE, Niskanen L, Punnonen K, Nyyssonen K, Tuomainen TP, Valkonen VP, Salonen R \& Salonen JT. Testosterone and sex hormone-binding globulin predict the metabolic syndrome and diabetes in middle-aged men. Diabetes Care 200427 1036-1041. (https://doi.org/10.2337/diacare.27.5.1036)

42 Vikan T, Schirmer H, Njolstad I \& Svartberg J. Low testosterone and sex hormone-binding globulin levels and high estradiol levels are independent predictors of type 2 diabetes in men. European Journal of Endocrinology 2010162 747-754. (https://doi.org/10.1530/EJE-090943)

43 Lakshman KM, Bhasin S \& Araujo AB. Sex hormone-binding globulin as an independent predictor of incident type 2 diabetes mellitus in men. Journal of Gerontology, Series A: Biological Sciences and Medical Sciences 201065 503-509. (https://doi.org/10.1093/gerona/ glq002)

44 Schipf S, Haring R, Friedrich N, Nauck M, Lau K, Alte D, Stang A, Volzke H \& Wallaschofski H. Low total testosterone is associated with increased risk of incident type 2 diabetes mellitus in men: results from the Study of Health in Pomerania (SHIP). Aging Male 201114 168-175. (https://doi.org/10.3109/13685538.2010.524955)

45 Soriguer F, Rubio-Martin E, Fernandez D, Valdes S, Garcia-Escobar E, Martin-Nunez GM, Esteva I, Almaraz MC \& Rojo-Martinez G. Testosterone, SHBG and risk of type 2 diabetes in the second evaluation of the Pizarra cohort study. European Journal of Clinical Investigation 201242 79-85. (https://doi.org/10.1111/j.13652362.2011.02559.x)

46 Jasuja GK, Travison TG, Davda M, Rose AJ, Zhang A, Kushnir MM, Rockwood AL, Meikle W, Coviello AD, D'Agostino R, et al. Circulating estrone levels are associated prospectively with diabetes risk in men of the Framingham Heart Study. Diabetes Care 201336 2591-2596. (https://doi.org/10.2337/dc12-2477)

47 Joyce KE, Biggs ML, Djousse L, Ix JH, Kizer JR, Siscovick DS, Shores MM, Matsumoto AM \& Mukamal KJ. Testosterone, dihydrotestosterone, sex hormone-binding globulin, and incident diabetes among older men: the Cardiovascular Health Study. Journal

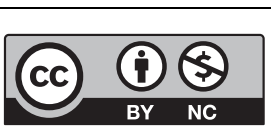

This work is licensed under a Creative Commons Attribution-NonCommercial 4.0 International License. 
of Clinical Endocrinology and Metabolism 2017102 33-39. (https:// doi.org/10.1210/jc.2016-2623)

48 Hu J, Zhang A, Yang S, Wang Y, Goswami R, Zhou H, Zhang Y, Wang Z, Li R, Cheng Q, et al. Combined effects of sex hormonebinding globulin and sex hormones on risk of incident type 2 diabetes. Journal of Diabetes 20168 508-515. (https://doi. org/10.1111/1753-0407.12322)

49 Salminen M, Vahlberg T, Raiha I, Niskanen L, Kivela SL \& Irjala K. Sex hormones and the risk of type 2 diabetes mellitus: a 9-year follow up among elderly men in Finland. Geriatrics and Gerontology International 201515 559-564. (https://doi.org/10.1111/ggi.12312)

50 Rao PM, Kelly DM \& Jones TH. Testosterone and insulin resistance in the metabolic syndrome and T2DM in men. Nature Reviews Endocrinology 20139 479-493. (https://doi.org/10.1038/ nrendo.2013.122)

51 Grossmann M. Testosterone and glucose metabolism in men: current concepts and controversies. Journal of Endocrinology 2014 220 R37-R55. (https://doi.org/10.1530/JOE-13-0393)

52 Tsai EC, Matsumoto AM, Fujimoto WY \& Boyko EJ. Association of bioavailable, free, and total testosterone with insulin resistance: influence of sex hormone-binding globulin and body fat. Diabetes Care 200427 861-868. (https://doi.org/10.2337/diacare.27.4.861)

53 Yeap BB, Chubb SA, Hyde Z, Jamrozik K, Hankey GJ, Flicker L \& Norman PE. Lower serum testosterone is independently associated with insulin resistance in non-diabetic older men: the Health In Men Study. European Journal of Endocrinology 2009161 591-598. (https://doi.org/10.1530/EJE-09-0348)

54 Xia F, Xu X, Zhai H, Meng Y, Zhang H, Du S, Xu H, Wu H \& Lu Y. Castration-induced testosterone deficiency increases fasting glucose associated with hepatic and extra-hepatic insulin resistance in adult male rats. Reproductive Biology and Endocrinology 201311106. (https://doi.org/10.1186/1477-7827-11-106)

55 Mitsuhashi K, Senmaru T, Fukuda T, Yamazaki M, Shinomiya K, Ueno M, Kinoshita S, Kitawaki J, Katsuyama M, Tsujikawa M, et al. Testosterone stimulates glucose uptake and GLUT4 translocation through LKB1/AMPK signaling in 3T3-L1 adipocytes. Endocrine 2016 51 174-184. (https://doi.org/10.1007/s12020-015-0666-y)

56 Sato K, Iemitsu M, Aizawa K \& Ajisaka R. Testosterone and DHEA activate the glucose metabolism-related signaling pathway in skeletal muscle. American Journal of Physiology: Endocrinology and Metabolism 2008294 E961-E968. (https://doi.org/10.1152/ ajpendo.00678.2007)

57 Kelly DM, Akhtar S, Sellers DJ, Muraleedharan V, Channer KS \& Jones $\mathrm{TH}$. Testosterone differentially regulates targets of lipid and glucose metabolism in liver, muscle and adipose tissues of the testicular feminised mouse. Endocrine $2016 \mathbf{5 4} 504-515$. (https://doi. org/10.1007/s12020-016-1019-1)

58 Fan W, Yanase T, Nomura M, Okabe T, Goto K, Sato T, Kawano H, Kato $S$ \& Nawata H. Androgen receptor null male mice develop lateonset obesity caused by decreased energy expenditure and lipolytic activity but show normal insulin sensitivity with high adiponectin secretion. Diabetes 200554 1000-1008. (https://doi.org/10.2337/ diabetes.54.4.1000)

59 Chakrabarti P \& Kandror KV. The role of mTOR in lipid homeostasis and diabetes progression. Current Opinion in Endocrinology, Diabetes and Obesity 201522 340-346. (https://doi.org/10.1097/ MED.0000000000000187)

60 Senmaru T, Fukui M, Okada H, Mineoka Y, Yamazaki M, Tsujikawa M, Hasegawa G, Kitawaki J, Obayashi H \& Nakamura N. Testosterone deficiency induces markedly decreased serum triglycerides, increased small dense LDL, and hepatic steatosis mediated by dysregulation of lipid assembly and secretion in mice fed a high-fat diet. Metabolism-Clinical and Experimental 201362 851-860. (https://doi.org/10.1016/j.metabol.2012.12.007)

61 Haring R, Baumeister SE, Volzke H, Dorr M, Felix SB, Kroemer HK, Nauck M \& Wallaschofski H. Prospective association of low total testosterone concentrations with an adverse lipid profile and increased incident dyslipidemia. European Journal of Cardiovascular Prevention and Rehabilitation 201118 86-96. (https://doi. org/10.1097/HJR.0b013e32833c1a8d)

62 Canguven O, Talib RA, El AW, Yassin DJ, Salman M \& Al-Ansari A. Testosterone therapy has positive effects on anthropometric measures, metabolic syndrome components (obesity, lipid profile, diabetes mellitus control), blood indices, liver enzymes, and prostate health indicators in elderly hypogonadal men. Andrologia 201749 e12768. (https://doi.org/10.1111/and.12768)

63 Permpongkosol S, Khupulsup K, Leelaphiwat S, Pavavattananusorn S, Thongpradit S \& Petchthong T. Effects of 8 -year treatment of long-acting testosterone undecanoate on metabolic parameters, urinary symptoms, bone mineral density, and sexual function in men with late-onset hypogonadism. Journal of Sexual Medicine 201613 1199-1211. (https://doi.org/10.1016/j. jsxm.2016.06.003)

64 Yassin AA, Nettleship J, Almehmadi Y, Salman M \& Saad F. Effects of continuous long-term testosterone therapy (TTh) on anthropometric, endocrine and metabolic parameters for up to 10 years in 115 hypogonadal elderly men: real-life experience from an observational registry study. Andrologia 201648 793-799. (https://doi.org/10.1111/and.12514)

$65 \mathrm{Pal} \mathrm{M} \&$ Gupta S. Testosterone supplementation improves glucose homeostasis despite increasing hepatic insulin resistance in male mouse model of type 2 diabetes mellitus. Nutrition and Diabetes 2016 6 e236. (https://doi.org/10.1038/nutd.2016.45)

66 Magnussen LV, Glintborg D, Hermann P, Hougaard DM, Hojlund K $\&$ Andersen M. Effect of testosterone on insulin sensitivity, oxidative metabolism and body composition in aging men with type 2 diabetes on metformin monotherapy. Diabetes Obesity and Metabolism 201618 980-989. (https://doi.org/10.1111/ dom.12701)

67 Kapoor D, Goodwin E, Channer KS \& Jones TH. Testosterone replacement therapy improves insulin resistance, glycaemic control, visceral adiposity and hypercholesterolaemia in hypogonadal men with type 2 diabetes. European Journal of Endocrinology $2006 \mathbf{1 5 4}$ 899-906. (https://doi.org/10.1530/eje.1.02166)

68 Dhindsa S, Ghanim H, Batra M, Kuhadiya ND, Abuaysheh S, Sandhu S, Green K, Makdissi A, Hejna J, Chaudhuri A, et al. Insulin resistance and inflammation in hypogonadotropic hypogonadism and their reduction after testosterone replacement in men with type 2 diabetes. Diabetes Care 201639 82-91. (https://doi.org/10.2337/ dc15-1518)

69 Muraleedharan V, Marsh H, Kapoor D, Channer KS \& Jones TH. Testosterone deficiency is associated with increased risk of mortality and testosterone replacement improves survival in men with type 2 diabetes. European Journal of Endocrinology 2013169 725-733. (https://doi.org/10.1530/EJE-13-0321)

70 Ho CH, Jaw FS, Wu CC, Chen KC, Wang CY, Hsieh JT, Yu HJ $\&$ Liu SP. The prevalence and the risk factors of testosterone deficiency in newly diagnosed and previously known type 2 diabetic men. Journal of Sexual Medicine 201512 389-397. (https://doi. org/10.1111/jsm.12777)

71 Gibb FW \& Strachan MW. Androgen deficiency and type 2 diabetes mellitus. Clinical Biochemistry 201447 940-949. (https://doi. org/10.1016/j.clinbiochem.2014.04.004)

72 Hamilton EJ, Davis WA, Makepeace A, Lim EM, Yeap BB, Peters KE $\&$ Davis TM. Prevalence and prognosis of a low serum testosterone in men with type 2 diabetes: the Fremantle Diabetes Study Phase II Clinical Endocrinology 201685 444-452. (https://doi.org/10.1111/ cen.13087)

73 Grossmann M. Low testosterone in men with type 2 diabetes: significance and treatment. Journal of Clinical Endocrinology and Metabolism 201196 2341-2353. (https://doi.org/10.1210/jc.20110118)

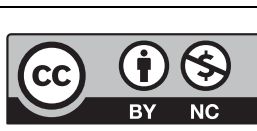

This work is licensed under a Creative Commons Attribution-NonCommercial 4.0 International License. 
74 Haring R, Ittermann T, Volzke H, Krebs A, Zygmunt M, Felix SB, Grabe HJ, Nauck M \& Wallaschofski H. Prevalence, incidence and risk factors of testosterone deficiency in a population-based cohort of men: results from the study of health in Pomerania. Aging Male 201013 247-257. (https://doi.org/10.3109/13685538.2010.487553)

75 Kapoor D, Channer KS \& Jones TH. Rosiglitazone increases bioactive testosterone and reduces waist circumference in hypogonadal men with type 2 diabetes. Diabetes and Vascular Disease Research 20085 135-137. (https://doi.org/10.3132/dvdr.2008.022)

76 Caronia LM, Dwyer AA, Hayden D, Amati F, Pitteloud N \& Hayes FJ. Abrupt decrease in serum testosterone levels after an oral glucose load in men: implications for screening for hypogonadism. Clinical Endocrinology 201378 291-296. (https://doi.org/10.1111/j.13652265.2012.04486.x)

77 Grossmann M, Thomas MC, Panagiotopoulos S, Sharpe K, Macisaac RJ, Clarke S, Zajac JD \& Jerums G. Low testosterone levels are common and associated with insulin resistance in men with diabetes. Journal of Clinical Endocrinology and Metabolism 200893 1834-1840. (https://doi.org/10.1210/jc.2007-2177)

78 Herrmann M, Scholmerich J \& Straub RH. Influence of cytokines and growth factors on distinct steroidogenic enzymes in vitro: a short tabular data collection. Annals of the New York Academy of Sciences 2002966 166-186. (https://doi.org/10.1111/j.1749-6632.2002. tb04213.x)

79 Hong CY, Park JH, Ahn RS, Im SY, Choi HS, Soh J, Mellon SH $\&$ Lee K. Molecular mechanism of suppression of testicular steroidogenesis by proinflammatory cytokine tumor necrosis factor alpha. Molecular and Cellular Biology 200424 2593-2604. (https:// doi.org/10.1128/MCB.24.7.2593-2604.2004)

80 Watanobe H \& Hayakawa Y. Hypothalamic interleukin-1 beta and tumor necrosis factor-alpha, but not interleukin-6, mediate the endotoxin-induced suppression of the reproductive axis in rats. Endocrinology 2003144 4868-4875. (https://doi.org/10.1210/ en.2003-0644)

Received in final form 3 December 2017

Accepted 12 December 2017

Accepted Preprint published online 12 December 2017 http://www.endocrineconnections.org https://doi.org/10.1530/EC-17-0253
(C) 2018 The authors Published by Bioscientifica Ltd

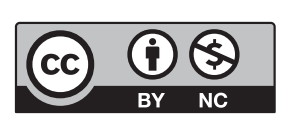

This work is licensed under a Creative Commons Attribution-NonCommercial 4.0 International License. 